\title{
Forces of Unworking in Virginia Woolf's “Time Passes”
}

\author{
Stefanie Heine
}

\begin{abstract}
The middle part of Virginia Woolf's To the Lighthouse, "Time Passes", presents a seemingly post-human setting in which destruction reigns. Read today, this scenario immediately evokes imaginations of the Anthropocene while resisting teleological notions of an end-time. Rather, "Time Passes" is pervaded by forces of unworking: agency slips into passivity, whatever is done becomes undone. A holiday house abandoned by human beings decays to "rack and ruin" until a group of cleaners attempts to reverse nature's work. Both the natural forces taking over and the cleaners engage in processes that are simultaneously destructive and productive. An analogous dynamic can be observed in Woolf's writing and editing practices: her laborious revisions mainly consist in deleting. As Woolf continually erases large parts of her writing, composition and decomposition are interwoven.
\end{abstract}

\section{E} cene became "conscious of itself" (Stiegler 2015, 129), she often imagined scenarios of extinction and states that come very close to what Deborah Bird Rose describes as the prevailing mood of being situated in the Anthropocene, that is, of "[b]eing overtaken by processes that are unmaking the world that any of us ever knew" $(2013,2){ }^{1}$ In The Waves, for example, Louis encourages us to listen

[. . . ] to the world moving through abysses of infinite space. It roars; the lighted strip of history is past our Kings and Queens; we are gone; our civilization; the Nile; and all life. Our separate drops are dissolved; we are extinct, lost in the abysses of time, in the darkness.

(Woolf 2000a, 173)

1. Recent research on Woolf is increasingly interested in reading her work through the lenses of ecocriticism and posthumanism. See, for example, TAZUDEEN 2015 and Kime Scott in Berman 2016. Research focusing on Woolf and the Anthropocene is also evolving; see, for example, TAYLOR 2016. 
Questions of ephemerality and durability, of what may last and what may vanish, preoccupied Woolf throughout her writing. Geological formations are described in terms of deep time: looking at the "dunes far away", Lily Briscoe, one of the protagonists of Woolf's To the Lighthouse, surmises that the "distant views seem to outlast by a million years" (2000b, 25), and Mr. Ramsay, a character in the same work, asks, "what are two thousand years? [. . .] What, indeed, if you look from a mountain top down the long wastes of the ages? The very stone one kicks with one's boot will outlast Shakespeare" (2000b, 41). While Woolf again and again takes into consideration that art - literature and painting, for example - has the capacity to endure, such assumptions are often severely qualified, sometimes undone: the stone outlasts Shakespeare. When Lily Briscoe reflects on the painting she works on assailed by doubt throughout the novel, she supposes, on the one hand, that it will not "pass and vanish", and, on the other, that it will end up "in the attics" or be "rolled up and flung under a sofa" (Woolf 2000b, 195). She continues her rumination as follows: "One might say, even of this scrawl, not of that actual picture, perhaps, but of what it attempted, that it 'remained for ever,' she was going to say, or, for the words spoken sounded even to herself, too boastful, to hint, wordlessly" (Woolf 2000b, 195). ${ }^{2}$

In this article, I want to look into what is described as a "wordless hint" towards the temporality of art and how it may remain. The ways in which Woolf outlines both the possible endurance and perishability of art in her novels challenge clear-cut oppositions of persistence and transience, permanence and termination. Woolf's writing in many respects confirms JeanLuc Nancy's claim that "'art' is above all the name of that which remains clear of ends and goals" (NANCY and Ricco 2015, 90). ${ }^{3}$ Thereby, it also escapes the logic of the teleological, "apocalyptic" implications of the Anthropocene (Sloterdij K 2015, 334) as a "narrative organized in terms of [its] ending [. . .], which attempts to evaluate the world from the perspective of its end" (Sloterdijk 2015, 330). Giorgio Agamben addresses the impending damage in the Anthropocene when he observes that "humanity [. . . ] has [. . .] developed its potency [potenza] to the point of imposing

2. For a discussion of this passage and the question of ephemerality and durability in Woolf's To the Lighthouse, see Rosner 2005, 170.

3. The context of this quoted passage is a conversation about the Anthropocene with John Paul Ricco, who addresses the "problematic of ends": "one might ask how the Anthropocene thesis is, or is not, yet another figuration of the "kingdom of ends"'; see NANCY and Ricco 2015, 89. 
its power over the whole planet" $(1999,177)$. Paradoxically, this power that threatens to destroy the planet is, in Agamben's own terms, a "constituent power" (2015, e.g. 266). Following the dynamic of what Horkheimer and Adorno described as the dialectic of enlightenment, in the Anthropocene men's ambitious operativity, through which they achieve power over nature, fuels progress and constructs and arranges the world for their benefit (c.f. 2013, esp. 9-15); rebounded, the "constituent power" is turning into a destructive one and humans are moving towards a self-inflicted apocalypse. Sloterdijk observes that, in the "ontology" of the Anthropocene, "the human being plays the dramatic animal on stage before the backdrop of a mountain of nature, which can never be anything other than the inoperative scenery behind human operations" (2015, 334). Even attempts to impede or restore the ecological damage in the sense of "eco political' action" (SLOTERDIJ 2015, 331), necessary as they are today, are situated in this very framework. In this respect, the "inoperative" may be more relevant than suggested by Sloterdijk's mention of it in a subordinate clause not further expanded on - provided that one does not consider it as the inferior contrast to the actions of "man" as a "major player" in the "game of global forces" (SLoterdijk 2015, 328), creating and destroying with godlike power.

As a force beyond active agency, inoperativity, and here we circle back to Agamben, represents an alternative to the logic of constitutive, destructive, and restorative power, which potentially resist it. Agamben describes inoperativity, the possible "access to a different figure of politics", as "destituent potential" $(2015,266)$ that "holds its own impotential or potential not-to firm" $(2015,276)$. In the same breath, he gives literary production as an example of inoperativity: "A poet is not someone who possesses a potential to make and, at a certain point, decides to put it into action" (2015, 276). That Agamben mentions the writer as an almost self-evident example for inoperativity presumably looks back to Maurice Blanchot's notion of désoeuvrement, or "unworking", a term which Agamben reinterprets. For Blanchot, who discusses unworking in the context of the emergence of artworks, "art is situated where [. . .] the artist has bit by bit removed from it [. . .] everything pertaining to active life" $(1989,47)$. Paradoxically, what makes a work possible "is the absence of all power, impotence" (BLANCHOT 1989, 108). For an artist, "wanting to produce a work, but not wanting to betray what inspires it", means seeking "to reconcile the irreconcilable and to find the work where he must expose himself to the essential lack of work, the essential inertia. This is a harrowing experience, which can be pursued 
only under the veil of failure" (BLANCHOT 1989, 185). 4 Such an exposure to failure, to the passive force of unworking, Blanchot continues, "is the infinitely hazardous movement which cannot succeed", but also the only possible way to create something that might be successful as a work of art $(1989,185)$. It goes without saying that in Blanchot's non-economic apprehension of the creative process, success is not granted thereby.

An awareness of potential failure pervades Lily Briscoe's reflections on the possible endurance of her painting, which she struggles to accomplish even as she is ridden with self-doubts, and also Woolf's personal "feeling of impotence" and fear of "failing to write well" (Woolf 1982, 28). In his essay on Woolf, focusing on A Writer's Diary, Blanchot points out how she, "so anxious, so uncertain", and, at the same time, so "carried by a prodigious movement" $(2003,103)$, engaged in a process of unworking initiated by voiding: "she must encounter the void ('the great agony,' 'the terror of solitude,' [ . . ]) in order, starting from this void, to begin to see” $(2003,99)$ and to write. For Blanchot, such a movement towards the void goes hand in hand with the articulation of a silence: "Art seems [. . . ] to be the silence of the world, the silence or the neutralization" (I989, 47). As he puts it elsewhere in the same work, "This silence has its source in the effacement toward which the writer is drawn" $(1989,27)$. In "Time Passes", the middle part of To the Lighthouse, Woolf depicts a scenario of effacement in which the silenced voices of the human characters are replaced by the hardly perceptible but persistent sounds of anonymized agencies. In the deserted holiday house, "stillness" reigns, the noise of the airs and the wind pervading it "scarcely disturbed the peace", "the swaying mantle of silence" (Woolf 2000b, 141). Silence "wove into itself" the natural sounds (Woolf 2000b, 141), and "the empty rooms seemed to murmur with the echoes of the fields and the hum of flies" (Woolf 2000b, 145).

"Time Passes" opens by presenting the diminishing voices of the characters in the holiday house hand in hand with a decrease of daylight. The ensuing nightfall introduces a post-apocalyptic setting: "So with the lamps all put out, the moon sunk, and a thin rain drumming on the roof, a downpouring of immense darkness began. Nothing, it seemed, could survive the flood, the profusion of darkness" (Woolf 2000b, 137). This sentence, recalling to readers the passage in The Waves stating, "we are extinct, lost in the abysses of time, in the darkness", marks the moment when the

4. In English, Blanchot's désoeuvrement is sometimes translated as "inertia", "lack of work", "unworking" or "worklessness". 
house, abandoned by human beings, starts being devoured by nature and decays to "rack and ruin" (Woolf 2000b, 150). Woolf herself describes her endeavour to write an increasingly voided space as follows in her diary: "I have to give an empty house, no people's characters, the passage of time, all eyeless \& featureless with nothing to cling to" $(1982,87)$. This task is a great challenge that triggers her uncertainty: "I cannot make it out - here is the most difficult abstract piece of writing" $(1982,87)$. Woolf's struggles with "Time Passes" and her writing and editing of the section is not unrelated to its contents (or rather lack of contents); in fact, one can observe that the production process of the text is reflected in it: a sense of unworking pervades both levels.

It is important to stress that such a sense of unworking neither exactly corresponds to what Blanchot outlines as désoeuvrement, nor to Agamben's reinterpretation of it in his notion of "inoperativity". This essay does not attempt to elucidate, or worse, give an example of what these writers have in mind. Nevertheless, those terms offer a framework against which Woolf's writing in To the Lighthouse can be read: the resonances, especially with Blanchot, are here alluded to in order to unfold Woolf's own expression of and engagement in forces of unworking. Bearing this in mind, and before focusing on the intersections between Woolf's writing process and what is depicted in "Time Passes", I want to point out a historical moment that constitutes the socio-political context in which it was written: the General Strike in 1926. While Woolf was struggling with a text in which almost nothing happens, the General Council of the Trades Union in the United Kingdom called a strike during which more than a million workers preferred not to, thus staging a gesture of resistance through inoperativity. In her diaries Woolf keeps mentioning the strike, a feeling of "deadlock" (Diary entry for 6th May 1926, not paginated) which, at times seems to pass on to her own preoccupation (and her husband Leonard's): "men in the street loafing instead of working. Very little work done by either of us today" (Diary entry for 7th May 1926, not paginated). One of her diary entries directly related to the strike, a description of an old couple affected by the suspension of public transport, is especially significant to our discussion of "Time Passes": "Among the crowd of trampers in Kingsway were old Pritchard, toothless, old wispy, benevolent [. . .] \& old Miss Pritchard, equally frail, dusty, rosy, shabby. 'How long will it last Mrs Woolf?"' (Diary

5. The question here is not Woolf's involvement or non-involvement in the strike, but rather how she integrated a certain mood of inoperativity in "Time Passes". For a study of Woolf's concrete political engagements, see Jones 2016. 
entry for 6th May 1926, not paginated). Out of this sketch of the Pritchards, the character of the housekeeper Mrs. McNab will be born. Similarly, the question, "How long will it last?", echoes throughout "Time Passes". The mood of the strike, of inoperativity, of the impaired, and the uncertainty about the outcome and end seeps its way into the text.

Despite its apocalyptic implications, the "downpouring of immense darkness" in "Time Passes" does not denote an endpoint; rather, other agencies subtly awaken with the disappearance of the humans. The abandoned house is invaded by forces of nature: even though the narrative voice, which seems to have fallen into an impersonal insomniac state, ${ }^{6}$ claims that "life had left it" (Woolf 2000b, 149), we observe what can be described as the "animation of the inanimate" (PAPApetros 2012), or the emergence of "vibrant matter" (BENnETt 2010) when airs, winds and plants start to ramble and spread. "[T]he fertility, the insensibility of nature" (Woolf 2000b, 150) results in overgrowth and proliferation and slowly makes the building corrode and decompose. Moreover, a fragile counterforce enters the scene as time passes: the housekeeper Mrs. McNab struggles to undo nature's both fertile and destructive work. And just as she is close to giving up a task that is bound to fail as her old body cannot handle the immense work, just before the house ultimately collapses, a troop of cleaners is mobilized to support her until the house is finally restored and made habitable again.

Nature's proliferation and the cleaners' cultivating obliteration, both tidying nature's sprawls, are analogous to Woolf's writing and editing processes, where productive and destructive forces are comparably interwoven. In a letter to Vita Sackville-West, Woolf addresses the struggles involved in writing "Time Passes": "I was doubtful about Time Passes. It was written in the gloom of the Strike: then I re-wrote it: then I thought it is impossible

6. David R. Sherman convincingly claims that “'Time Passes' achieves what might be called a narrative insomnia, a preternatural vigilance in the narrator that exceeds the available means of being a subject" (168). He describes this "insomniac consciousness" as "a mind that has fallen out of the dialectic of waking and sleeping, being and nothingness. [. . .] [It] makes less sense, loses its bearings, is unable to return to itself in a self-recognizing embrace after an absence" (I68-9). In this context, Sherman references Blanchot's essay "The Narrative Voice". What Blanchot outlines as a neutral voice articulating literary texts is very accurate with regards to the narrative situation of "Time Passes": In order to avoid the impression that "Time Passes" is told by a personified narrator, I use the more impersonal term "narrative voice". See Sherman 2007 and BlanСHOT 1982. 
as prose" $(1977,374)$. Her comment about the revisions points to a compositional-decompositional movement that, like both the natural forces and cleaners' work, is characteristic of her editing practice in general and can be summarized by her comment on her intentions in The Waves: "[W]hat I want now to do is to saturate every atom. I mean to eliminate all the waste, deadness, superfluity" (Woolf 1977, 209). ${ }^{7}$ Woolf's revisions in To the Lighthouse are mostly determined by reducing, deleting, tightening and condensing. In her diary, Woolf comments on writing the manuscript of "Time Passes" and mentions that she is "flown with words", but that the text "needs compressing" $(1982,87)$. After having completed the first holograph draft, consistently writing about two pages a day over the period of almost a month, that is, after systematically producing written material, the text is reduced in the typescript and even more so in the printed version. ${ }^{8}$ Whereas not much is added, many passages are either fully deleted or compressed. The structure of the chapter as a whole and the array of the scenes already given in the manuscript, however, remain almost unchanged. The holograph draft in which many words and sentences are already blotted out after a first review is akin to the stone block out of which a sculpture is chiselled.

When revising To the Lighthouse, Woolf is thus involved in a laborious, time-consuming and exhaustive process of removing surplus material. Here we can see a clear parallel to the cleaners' work on the fictional level of "Time Passes", who are "rubbing", "dusting", "wiping” (Woolf 2000b, 142), "sweeping" (Woolf 2000b, 145), "mopping, scouring" (Woolf 2000b, 151). The parallels between Woolf's revising practice and the cleaners' work accrue across the text. When Woolf writes, in reference to the cleaners' work, that "[s]ome rusty laborious birth seemed to be taking place"

7. In The Making of Samuel Beckett's L'Innommable / The Unnamable, Dirk van Hulle and Shane Weller observe a comparable dynamic in Beckett's self-translation and revisions of The Unnamable, which they describe as a process of "selfdecomposition" (191). Their genetic analysis of the drafts for The Unnamable points out a "movement towards a radically new form of what might be termed unwriting" (21). Despite the basic similarities - composition becomes decomposition - Woolf's concrete editing practice differs fundamentally from Beckett's and the concrete examples of "unwriting" given by van Hulle and Weller hardly overlap with what I will outline as forces of unworking. See Hulle and Weller 2014 .

8. The holograph draft has around 11,180 words, the typescript around 7,000 words, and the printed version around 5,750 words. Cf. Woolf Online, a digital archive of Virginia Woolf's To the Lighthouse. 
(2000b, 152), she may also be referring to the emergence of writing. We hear, moreover, echoes of Mrs. Mc Nab's complaint that "there was too much work for one woman", and of the cleaners' sigh, "Oh, [. . .] the work!" (Woolf 2000b, 152), in Woolf's articulations of her somatic experience of the difficult writing and revising process of To the Lighthouse: "I so soon tire of work" $(1982,28)$. Reading the exclamation "Oh, [. . .] the work!” as a self-reflexive comment about the writing process is encouraged by the double meaning of "work", as labour and as literary work. The words "it was finished" (Woolf 2000b, 153), articulated after the cleaners complete their task, could also be applied to the writing process, as the passage draws to an end at this point. The expressions "Oh, they said, the work!" and "it was finished" do not appear in the holograph draft, which points to the fact that the writing process at its specific stage is reflected in the various versions: the anticipation of a finished work is more present in the typescript and fulfilled in the printed version, whereas it is not yet in sight in the holograph draft, where only the "labour" (Woolf Draft, 164) and the "laborious birth" (Woolf Draft, 180) are mentioned. ${ }^{9}$ As a last example of the parallelism between the work of cleaning and writing, when nature's forces ravage the house, the narrative voice claims that "[n] othing now withstood them; nothing said no to them" (Woolf 2000b, 150), while what characterises Woolf's writing practice most is saying "no" to rampant language.

Cutting the linguistic proliferations implies that composition and decomposition go hand in hand: by deleting more and more, Woof continually destroys parts of the text she created. If we look at pages of the holograph draft, the deletions evoke the impression of the text being harmed or in decay. At the same time, the destruction of parts of the text in the drafts is what enables the realisation of the text in its final form. In this way, Woolf's editing processes echo a dynamics of unworking in a Blanchotian sense. Blanchot himself, who was aware that Woolf was "rewriting each of her books I don't know how many times" (BLANCHOт 2003, 101), describes such a practice as follows: "everything original is put to the test by the sheer powerlessness inherent in starting over — this sterile prolixity, the surplus of that which can do nothing, which never is the work, but ruins it and in it restores the unending lack of work" $(1989,37)$. It is precisely the "sterile prolixity" of "starting over", revising again and again, which makes writing

9. All citations from the draft and the typescript are taken from Woolf Online and reproduced with the kind permission of The Society of Authors as the Literary Representative of the Estate of Virginia Woolf. 
"interminable" and "incessant" (Blanchot 1989, 26). For Blanchot, "to write is [. . .] to surrender to the risk of time's absence, where eternal starting over reigns" $(1989,33)$. Obviously, "Time Passes" does not present an absence of time as such, but, in line with Blanchot's implication, it stages a movement of "eternal starting over", of unworking on the fictional level, which at the same time preserves traces of a writing and editing process determined by a corresponding dynamic.

What is abandoned in such a dynamic is the idea of an ultimate finality, an end of times. In this respect, it is significant that "Time Passes" is set during World War One, deliberately focusing on a temporally alternative scenario to the war, which was conceived as the end of civilization by many of Woolf's contemporaries. Here and there, Woolf famously inserts brief factual scraps from the parallel scenario of the War in her text, stressing the finality of its temporal logic by using square brackets, i.e., "[A shell exploded. Twenty or thirty young men were blown up in France, among them Andrew Ramsey, whose death, mercifully, was instantaneous]" (2000b, 145). Within the chapter as a whole, the seeming closure of the square brackets is undermined, as they represent an interruption, and not a termination of the temporal proceedings in the abandoned house, which, I argue, may offer us a way to approach a notion of the Anthropocene beyond the apocalyptic logic, an Anthropocene, that is, determined by forces of unworking rather than a linear teleological path towards destruction.

To return to the parallels between the fictional level of "Time Passes" and Woolf's writing and editing processes: Woolf's deletions are not only comparable to the cleaners' work, but also to the decomposing forces of nature, especially the "nibbling" airs. The airs' work resembles Woolf's deleting process through the corroding act of nibbling: In both the holograph draft and the typescript they are called "spies" (Woolf Draft, 157; Typescript, 4, 6) and repeatedly described as beady-eyed agents moving about the house. In the holograph draft, the air-spies are described as a "stealthy patrol" (Woolf, 156), "prying \& peering" (Woolf, 155). Such a militant surveillance also corresponds to Woolf's insistent review and inspection of her drafts as a prerequisite for her relentless corrections and deletions. It is no contradiction that hints to Woolf's editing process can be found both in the description of what the airs and the cleaners do and undo. It would be incorrect to assume that the cleaners' work is purely reconstructive and that of the natural forces purely destructive.

The closer we look at the text, the more obvious it gets that their operations - or, shall we say inoperations? - are analogous. The airs and 
the cleaners are engaged in a process of unworking where productive and destructive forces intertwine: the animate airs contribute to the house's impending collapse, whereas the cleaners undo nature's "fertile work" and thereby restore the damaged house. Their respective doings are highly precarious and constantly on the verge of diminishing or turning into resignation and inertia. The airs are frail, hardly visible, barely perceptible: when they are first described, the narrative voice keeps speculating about the hour that their movement through the house will "cease" (Woolf 2000b, 138). In a similar fashion, the narrative voice stresses the weakness and mortality of Mrs. McNab's body: "she was too old. Her legs pained her" (Woolf 2000b, 147). It is precisely these feeble and faint entities, whose endurance is, literally, constantly put into question, that persevere. The disembodied airs who constantly almost "cease" and "disappear" (Woolf 2000b, 138), "iterate[] and reiterate[]": "we remain" (Woolf 2000b, 141). In turn, Mrs. McNab and the cleaners finally do stay and restore the house.

The relation between the cleaners, Mrs. Mc Nab and the airs exceeds analogy: they are rather presented as various figurations of the same force of unworking. When Mrs. McNab temporarily gives up her task of reverting nature's work, "the trifling airs, nibbling, the clammy breaths, fumbling, seemed to have triumphed" (Woolf 2000b, 150). The airs are no longer mentioned when the cleaners succeed in restoring the house, which may imply that the cleaners "triumphed". However, the way in which the cleaning women move around the house, "stooping, rising, groaning, singing", how they "lapped and slammed, upstairs now, now down in the cellars" (Woolf 2000b, 152), is strikingly similar to how the airs "crept" around "corners", "entered the drawing-room", "mounted the staircase and nosed round bedroom doors" (Woolf 2000b, 138). Returning to earlier descriptions of Mrs. McNab, too, one can observe a strange correlation between her and the airs, even in the words with which Woolf describes them: they both "sigh[]" (Woolf 2000b, 139, 149) and "rub[]" (Woolf 2000b, 138, 142). Certain words and attributes are thus transferred from the airs to Mrs. McNab. Rather than being agents that respectively attempt to cancel each other out, the airs and the cleaners persist in an incessant process of doing and undoing - and what the personified airs give as an answer to their repeated question of what will endure, namely "we remain" (Woolf 2000b, 141), is affirmed: their movement is maintained in Mrs. McNab's work. Immediately before the cleaners return to the house, we find the following sentence: "But there was a force working; something not highly conscious; something that leered, something that lurched; something not inspired to go about its work with dignified ritual or solemn chant- 
ing. Mrs. McNab groaned; Mrs. Bast creaked" (Woolf 2000b, 151). The most straightforward interpretation would be to identify this "force" with the cleaners. But why would the cleaners be called "something", and why would they be "not highly conscious"? Rather than equating it with Mrs. $\mathrm{McNab}$ and her helpers, "the force" may refer to the movement shared by the airs and the cleaners, which also manifests itself in the transference of attributes from the airs' activity to the activity of the cleaners. Operating in a subliminal, semi-dormant rather than an active way, the paradoxically persistent force of unworking shows how the text as such "works".

In this context, the question of the cleaners' social status has to be addressed. ${ }^{10}$ In The Labors of Modernism, Mary Wilson claims "Woolf's domestic modernism [. . .] depends on, and continues to be invested in, the visible invisibility of servant labor, while it creates a style of modernist narrative that borrows from that very structure" $(2016,23)$. It is precisely in the parallels created between the servants' and the writers' work, or the literary work, that Wilson observes a perpetuated structure of exploitation: "their home-making labors are inscribed in, and often exploited by, the novel-making labors of modernist writing" $(2016,10)$. As Alison Light convincingly shows, Woolf's depictions of servants reproduce some of the "prejudices about the 'lower orders' [that] were typical of the day" (2008, xviii) and portraits like the one of Mrs. Mc Nab as a kind of inarticulate "archetypal species" $(2008,200)$ certainly involve problematic mystifications. I would argue that the continuity between the cleaners, the airs, Woolf's editing practice and the text's own movement - when considered in terms of unworking - at least to some degree resists both these prejudices/mystifications and the exploitative mechanism Wilson points out in attempts to assimilate modernist writing and servant labor. Unworking breaks with an "economy of dependence" (WILson 2016, 30) and unsettles the space of middle class domesticity. As a force countering the realization of getting work accomplished or done, unworking is situated outside the logic of economy as such. The relations between the agents in the house that is no longer a home are complex and escape linear hierarchy: in their attempts to domesticate it again, the cleaners mirror how the airs undo the domestic space. The goal of the cleaners' work on the diegetic level, to make the house habitable again "for the upper classes" (Light 2008, 200), is undermined by the form their work takes on, the way in which it slips into unworking. That the cleaners' movements, sounds and words

10. I am grateful for Amanda Golden's advice to address this issue as well as her suggestions for further reading. 
contain both traits of the airs and of Woolf's editing practice complicates established social power relations. The fact that they are the most conspicuous trace of that editing practice in the finished novel almost reverts the idea that the servants' work is rendered invisible in the writers' work it makes possible. Finally, the cleaners' affinity to the airs and the impersonal space of writing as well as the insistence of the passive force the cleaners exert, their potential to remain, maybe remain after extinction, in a postapocalyptic world, shifts them to a domain beyond the human, ${ }^{11}$ and thus beyond socio-political power relations. ${ }^{12}$

What becomes apparent if one traces the course of Woolf's editing process, which, as it has been observed, mainly consists in reducing textual material, is that she lets the occurrence of human characters diminish. In the first draft and the typescript, "sleepers", very possibly the sleeping guests of the holiday house, that is, the characters whom we got to know in the first part of the novel, are present as actual human bodies in the initial stages of the house's decay. Even though the sleepers are described as waning, they are still there:

Not only was furniture confounded; but there was scarcely anything left of body or mind by which one could say 'this is he' or 'this is she'; but from the many bodies lying asleep either in the rigid attitudes of the old passively creased in the creases of the beds, or easily lying scarcely covered, in childhood [. . . there rose, to break silvery on the surface, thoughts, dreams, impulses, of which the sleepers by day knew nothing. Now a hand was raised as if to clutch something or perhaps ward off something; now the anguish which is forbidden to cry out for comfort parted the lips of the sleepers; now and then somebody laughed out loud, as if sharing a joke with nothingness.

(Woolf Typescript, 1)

In the printed version, this passage, unlike many others where the sleepers occur in draft and typescript, is carried over, but the sleepers them-

11. Depersonalizing the cleaners (Wilson 2016, 53) and stressing their passivity would in that sense by no means reproduce the common prejudice against domestic laborers, but rather provide a re-evaluation and rethinking of the widespread devaluation of passivity and of anthropocentrism in a society that builds on social exploitation.

12. Rather than calling into question readings like Light's or Wilson's, I argue that the reproduced power relations they importantly point out are accompanied and at times counteracted by other implications. 
selves have disappeared. The "hand" is raised out of nowhere, the laughter is no longer tied to "the lips of the sleepers". What in draft and typescript belonged to slumbering humans now occurs in a disembodied manner: "there was scarcely anything left of body or mind by which one could say, 'This is he' or 'This is she.' Sometimes a hand was raised as if to clutch something or ward off something, or somebody groaned, or somebody laughed aloud as if sharing a joke with nothingness" (Woolf 2000b, 1378). In the only instance where a sleeper occurs in the printed version, it does so hypothetically: "should any sleeper fancying that he might find on the beach an answer to his doubts, a sharer of his solitude, throw off his bedclothes and go down by himself to walk on the sand" (Woolf 2000b, 140). In the draft and the typescript, the sleepers, who explicitly linger "in the house" (Woolf Draft, 187), sometimes somnambulate outside: "so the wind may have answered the sleepers, the dreamers, pacing the sand" (Woolf Typescript, 2). Thus, in the early versions of "Time Passes" there is a narrative continuity to "should any escaped soul, any sleeper, who fancies that in sleep he has grasped the hand of a sharer walk the edge of the sea" (Woolf Typescript, 6), and the hypothetical sleepers clearly go back to actual ones.

Hand in hand with the depersonalization of the sleepers, a realization of the endeavour "to give an empty house, no people's characters", qualities that are in the first draft attributed to Mrs. McNab's "incongruous song" (Woolf Draft, 164) are transferred to the airs. Whereas we can observe a movement of incorporation of the airs in the body of the cleaners as the middle part turns towards its end within all various drafts, including the final version, a reverse movement can be detected if we look at the development of the text across the drafts: human characters become more and more depersonalized and the "sound issued" from a human character's "lips" (Woolf Typescript, 9) emerges from the disembodied airs. Here it is worth comparing the description of Mrs. McNab's song in the first draft and the printed version. In all versions, the "song", or rather remains of a song Mrs. $\mathrm{McNab}$ utters during her exhaustive work, is depicted as being in a derelict state. The printed version puts it as follows: "something that had been gay twenty years before on the stage perhaps, had been hummed and danced to, but now, coming from the toothless, bonneted, care-taking woman, was robbed of meaning, was like the voice of witlessness" (Woolf 2000b, 142). In the first draft, this ruinous singing appears to us in an accordingly decomposed language, a language that shares this quality with the song it describes precisely because it is in composition, in the process of becoming: 


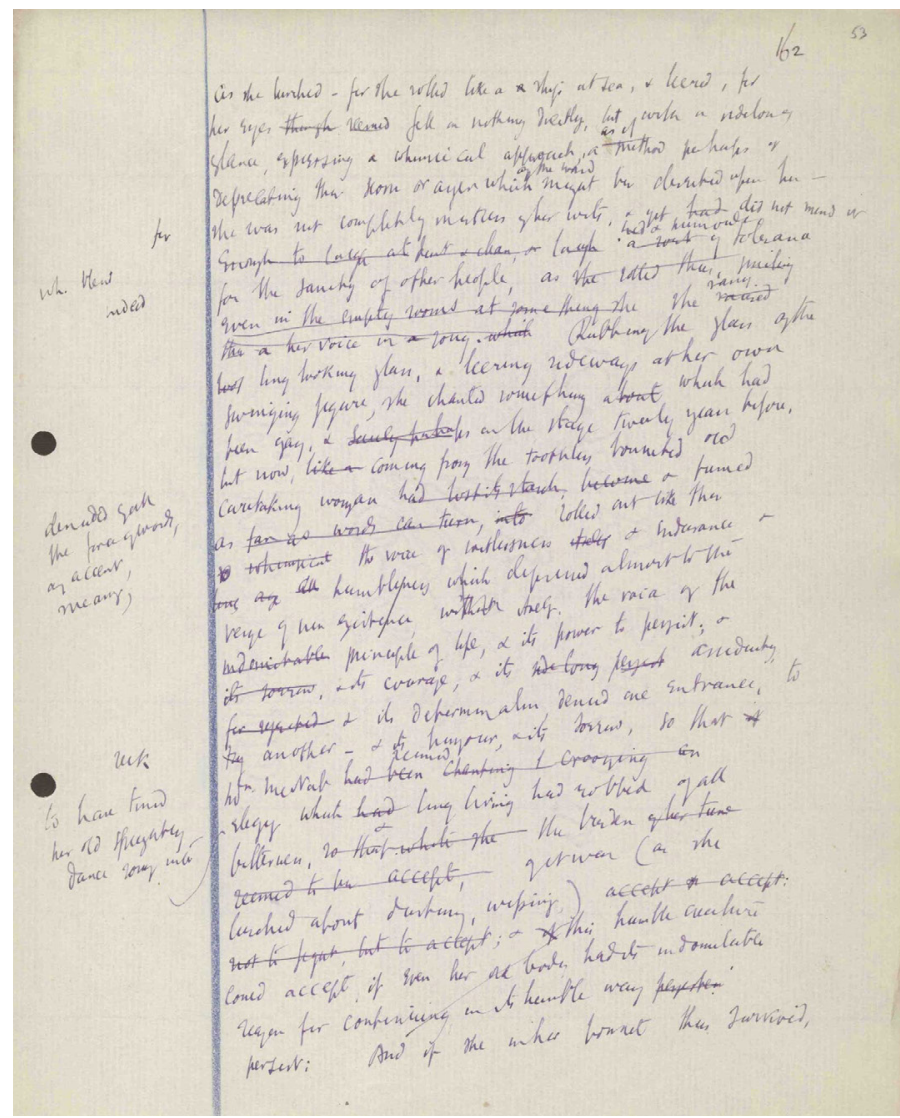

Figures 1 and $1 \mathrm{a}$.

Virginia Woolf, draft page of "Time Passes". Holograph MS, Berg Collection. New York Public Library. The image here is from Woolf Online and is reproduced by the kind permission of The Society of Authors as the Literary Representative of the Estate of Virginia Woolf.

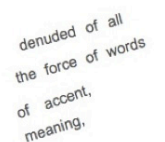

$$
\begin{aligned}
& \text { swinging nyuic, a... } \\
& \text { been gay. \& surely perhaps on the stage twenty years }
\end{aligned}
$$


In the draft, the fluid transition between Mrs. McNab's "voice of witlessness itself \& endurance", the "voice of the indomitable principle of life and its power to persist" (my emphases) and the air's speech is much more obvious than in the description of it in the printed version. The airs' "light persistency of feathers" (Woolf 2000b, 138) is echoed, and the word "endurance" recalls the question "how long would they endure" (Woolf 2000b, 138), which, in the draft is uttered by the narrative voice describing the airs, and then, in the later versions, by the airs directly, in their own "voice of witlessness". In contrast to the draft, the printed version also lets this question echo word by word in Mrs. McNab's mouth: "how long shall it endure?" (Woolf 2000b, 143), she asks about the work. Thus, the airs' and the cleaners' inoperative voices and words interweave.

That Mrs. McNab's dirge expresses "some incorrigible hope" (Woolf $2000 \mathrm{~b}, 143$ ) in the light of her almost unmanageable task can also be read as a reference to Woolf's editing practice: her corrections themselves rest upon something "incorrigible", the hope that they will at some stage lead to a finished text. Hope and lament meet in the moment a process of unworking is reflected. It is a moment of utter uncertainty in which everything is simultaneously falling apart and coming together - a moment that, when it is depicted on the fictional level of "Time Passes", maintains traces of how the text itself came to be: the instances when it was a ruinous progress, a feeble construct tattered by deletions whose outcome was not granted. This can only be met with a sigh - a communal, anonymous sigh of lament and perseverance like the one uttered by the airs and the creaking of the obstacles they meet: "At length, desisting, all ceased together, gathered together, all sighed together; all together gave off an aimless gust of lamentation" (Woolf 2000b, 139). A "murmur of the incessant and interminable" (BLANCHOт 1989, 48) that in Woolf's text moves from breath to air and back, gets embodied and disembodied, and mediates between the finished text and the traces of its emergence. The three scenarios investigated here articulate an elegy of unworking: while the feeble airs pervade the deserted house, Mrs. McNab forces her aching body to work and Woolf cuts her way through "the most difficult abstract piece of writing" in which the proximity to resignation, "rack and ruin" and "oblivion" is stifling. Maybe as stifling as an age termed the "Anthropocene", in which the apocalyptic narrative of the end of time almost seems to relieve the uncertainty we encounter, and when a sentence like the opening of "Time Passes", "Well, we must wait for the future to show" (Woolf 2000b, 127), may be overshadowed by more severe ruminations: "The disaster takes care 
of everything. [. . . ] Nothing suffices to the disaster; this means that just as it is foreign to the ruinous purity of destruction, so the idea of totality cannot delimit it" (Blanchot 1986, 3, 2).

University of Zürich

\section{Works Cited}

Agamben, Giorgio. 2015. The Use of Bodies, translated by Adam Котsко. Stanford: Stanford University Press.

- 1999. Potentialities. Collected Essays in Philosophy, edited and translated by Daniel Heller-Roazen. Stanford: Stanford University Press.

Bennett, Jane. 2010. Vibrant Matter. A Political Ecology of Things. Durham and London: Duke University Press.

Bird Rose, Deborah. 2013. "Anthropocene Noir". People and the Planet 2013 Conference Proceedings, edited by Paul James et al., 1-11. Melbourne: Global Cities Research Institute.

Blanchot, Maurice. 2003. The Book to Come, translated by Charlotte Mandell. Stanford: Stanford University Press.

1989. The Space of Literature, translated by Ann Sмоск. Lincoln: University of Nebraska Press.

1986. The Writing of the Disaster, translated by Ann Sмоск. Lincoln and London: University of Nebraska Press.

1982. "The Narrative Voice or the Impersonal 'He". In The Siren's Song. Selected Essays of Maurice Blanchot, edited by Gabriel Josıpovici, 213-21. Brighton: Harvester Press.

Caughie, Pamela L., Nick Hayward, Mark Hussey, Peter Shillingsburg, and George K. Thiruvathukal, eds. 2011-2019. Woolf Online. Web. 1 Feb. 2019. http://www.woolfonline.com.

Davis, Heather and Etienne Turpin. 2015. "Art \& Death: Lives Between the Fifth Assessment \& the Sixth Extinction". In Art in the Anthropocene. Encounters Among Aesthetics, Politics, Environments and Epistemologies, edited by Heather Davis and Etienne Tur pin, 3-29. London: Open Humanities Press.

Horkheimer, Max and Theodor W. Adorno. 2013. Dialektik der Aufklärung. Frankfurt am Main: Fischer.

Jones, Claire. 2016. Virginia Woolf. Ambivalent Activist. Edinburgh: Edinburgh University Press.

Kime Scott, Bonnie. 2016. "Ecocritical Woolf". In Companion to Virginia Woolf, edited by Jessica Berman, 291-331. London: John Wiley \& Sons, Ltd.

Light, Alison. 2008. Mrs. Woolf and the Servants. An Intimate History of Domestic Life in Bloomsbury. New York: Bloomsbury.

NANCy, Jean-Luc, and John Paul Ricco. 2015. "The Existence of the World Is Always Unexpected”. In Art in the Anthropocene. Encounters Among Aesthetics, Politics, 
Environments and Epistemologies, edited by Heather Davis and Etienne Turpin, 85-92. London: Open Humanities Press.

Papapetros, Spyros. 2012. On the Animation of the Inorganic. Art, Architecture, and the Extension of Life. Chicago and London: University of Chicago Press.

Rosner, Victoria. 2005. Modernism and the Architecture of Private Life. New York: Columbia University Press.

Sherman, David. 2007. "A Plot Unraveling into Ethics: Woolf, Levinas, and 'Time Passes". Woolf Studies Annual 13: 159-79.

Sloterdijk, Peter. 2015. "The Anthropocene: A Process-State at the Edge of Geohistory?" In Art in the Anthropocene. Encounters Among Aesthetics, Politics, Environments and Epistemologies, edited by Heather Davis and Etienne Tur Pin, 327-40. London: Open Humanities Press.

Stiegler, Bernard. 2015. "Automatic Society 1: The Future of Work - Introduction". La Deleuziana 1. Crisis of the European Biopolitics: 121-40.

TAy Lor, Jesse Oak. 2016. The Sky of Our Manufacture. The London Fog in British Fiction from Dickens to Woolf. Charlottesville: University of Virginia Press.

TAzudeen, Rasheed. 2015. "'Discordant Syllabling': The Language of the Living World in Virginia Woolf's Between the Acts”. Studies in the Novel 47.4: 491-513.

van Hulle, Dirk and Shane Weller. The Making of Samuel Beckett's L'Innommable / The Unnamable. London: Bloomsbury, 2014.

Wilson, Mary. 2016. The Labors of Modernism. Domesticity, Servants, and Authorship in Modernist Fiction. New York: Routledge.

Woolf, Virginia. 2011-2019. "Diary", in Caughie, Pamela L., et al., 2011-2019. Woolf Online. Web. 19 June 2018. http://www.woolfonline.com/?node=content/contextual $/$ transcriptions\& project $=1 \&$ parent $=41 \&$ taxa $=42 \&$ content $=6311 \&$ pos $=15$

_ . 2011-2019. Draft of “Time Passes". Holograph MS. Berg Collection. New York Public Library, reproduced in Caughie, Pamela L., et al., 2011-2019. Woolf Online. Web. 19 June 2018. http://www.woolfonline.com.

—_. 2011-2019. Typescript of "Time Passes", reproduced in Caughie, Pamela L., et al., Woolf Online. Web. 19 June 2018. http://www.woolfonline.com.

- 2000a. The Waves, edited by Kate Flint. London: Penguin Classics.

. 2000b. To the Lighthouse, edited by Stella McNichol. London: Penguin Classics.

1982. A Writer's Diary. Being Extracts from the Diary of Virginia Woolf, edited by Leonard Woolf. New York: Harcourt.

. 1977. The Letters of Virginia Woolf. Volume III. 1923-1928. A Change of Perspective. London: Hogarth Press. 